\title{
Reduction of the oestrogenic effect of zearalenone in pigs by a feed additive
}

\author{
Endre Brydl ${ }^{1}$, András Ványi ${ }^{\dagger}$, Róbert Glávits ${ }^{2}$, László Könyves ${ }^{1}$, Pál Rafai ${ }^{1}$ \\ ${ }^{1}$ Szent István University, Faculty of Veterinary Science, Department of Animal Hygiene, \\ Herd Health and Veterinary Ethology, Budapest, Hungary \\ ${ }^{2}$ Central Veterinary Institute, Budapest, Hungary \\ departed
}

Received February 25, 2013

Accepted October 23, 2013

\begin{abstract}
Zearalenone is phenolic resorcyclic acid lactone produced by a number of Fusarium species grown on grains, predominantly on maize, in high moisture environment. Due to its oestrogenic effects, feeds contaminated with zearalenone can cause striking negative effects on reproduction primarily in pigs. The aim of the study was to test the efficiency of a feed additive developed for enzymatic decomposition of mycotoxins. A total of sixty 6-week-old conventional Dutch Landrace $\times$ Hungarian Large White $\mathrm{F}_{1}$ female pigs weaned at $30 \pm 2$ days of age were divided into 6 groups of 10 animals. Between 50 and 70 days of age, 4 groups of pigs (experimental) were treated with zearalenone ( 8 or $16 \mathrm{mg} / \mathrm{pig}$ dose) administered every other day via an oesophageal tube; pigs from the other two groups were not treated with zearalenone and served as controls. Throughout the experiment, the diet of two experimental groups and one control group was supplemented with a feed additive (named: Detoxa Plus) at a concentration of $1 \mathrm{~kg} /$ tonne; pigs from the other control group received neither zearalenone treatment, nor the feed additive. Pigs' live weight, weight of ovaries and uterus, histological characteristics of the ovaries, uterus, vagina, spleen and lymph nodes, liver concentrations of zearalenone and its metabolites ( $\alpha$ - and $\beta$-zearalenol) were studied. This study showed the preventive capacity of the feed additive against zearalenone. Positive effects included the prevention of uterine enlargement, beneficial effects on the histopathological scores of ovaries, uterus and vagina and reduced concentration of zearalenone and metabolites in the liver. This study demonstrates for the first time that due to its enzymatic activity Detoxa Plus renders zearalenone contaminated feeds less toxic.
\end{abstract}

Biodegradation, biotransformation, Detoxa Plus, F-2 fusarium toxin, oestrogenism

The contamination of feedstuffs with zearalenone (ZEA), an oestrogen-mimetic mycotoxin, has been known for a long time and caused considerable reproductive failures in pigs which is considered the most sensitive farm animal (Zinedine et al. 2007; Lawley et al. 2008). The main effects of zearalenone rely on its interaction with oestrogen receptors resulting in apparent hyperoestrogenism, including reduced fertility (Anonym 2004).

It is generally agreed that farm animals should be protected against the adverse effects of mycotoxins. The methods of protection have been described by many authors (e.g. Rafai 1999; Halász et al. 2009). Recently, the use of microorganisms for biotransformation/ biodegradation of mycotoxins has gained importance (Heidler and Schatzmayr 2003). Detoxa Plus (manufacturer: Dr. Bata Closed Shareholder Co., H-2364, Ócsa, Pesti úti major, Hungary), has been specially developed for enzymatic decomposition of mycotoxins in animal feeds via its active germ components (BD 21 strain, Pichia membranae faciens). The steps of detoxification have been described by Bata and Lásztity (1999).

The aim of the present study was to test the efficiency of the above feed additive in reducing the presumed negative effects of purified zearalenone on growing pigs.

\section{Materials and Methods}

This experiment was approved by the Animal Use and Care Administrative Advisory Committee of the Municipal Veterinary Service for Animal Protection (Nr.: 362/003/2004) and was in agreement with the Ethical 
Codex of the Hungarian Association of Laboratory Animal Science and with the principles of the Hungarian Animal Welfare Act adopted by the Hungarian Parliament (Act No. XXVIII/98).

A total of sixty 6-week-old conventional Dutch Landrace $\times$ Hungarian Large White $F$ female pigs weaned at $30 \pm 2$ days of age were selected from 20 litters and allocated on basis of weight and conformation into 6 groups of 10 animals and reared further to 90 days of age on a commercially available starter feed. At the establishing of the groups, care was taken to avoid allocating littermates into the same group. The average weight of pigs at weaning was $8.4 \pm 0.3 \mathrm{~kg}$. Pigs were put into flat decks equipped with stainless steel feed troughs, nipple drinkers and aluminium-cast slatted floor at a population density of 5 piglets/pen with $0.6 \mathrm{~m}^{2} \mathrm{resting}$ area/pig. The flat decks were housed in climatically controlled nursery at optimum ambient temperature, relative humidity and air velocity. A 12 h/day light regime was used. The time between assembly and start of the experiment at 50 days of age (preliminary period) allowed the pigs to adapt to the housing, feeding and caring conditions.

During 50-70 days of pig age (experimental period of 20 days), four groups (groups 3-6) of pigs were treated with purified zearalenone, dissolved in propylene-glycol at a concentration of $1 \mathrm{mg} / \mathrm{ml}$ and administered every other day to pigs at 9.00 a.m. via oesophageal tube either at a dose of 8 (group 3 and 4 ) or 16 (group 5 and 6) mg/pig. The remaining two groups (group 1 and 2) were not treated with zearalenone and served as controls. Pigs from these two control groups were sham treated with propylene-glycol parallel with the treatment of the experimental pigs with zearalenone. The diets of two experimental groups treated with 8 (group 4) and $16 \mathrm{mg}$ /day zearalenone (group 6) and one control (group 2) were supplemented with the feed additive at a concentration of $1 \mathrm{~kg} /$ tonne.

At 70 days of age the experiment was finished, however, a 20-day terminal period was applied for clearing the pigs of zearalenone. The experimental design is shown in Table 1.

Purified zearalenone was prepared by fermentation of Fusarium graminearum on rice substrate as described previously (Bata et al. 1989; Ványi et al. 1994).

On Days 10 and 20 of the experimental period and at the end of the terminal period, 3, 4 and 3 pigs, respectively, were sacrificed from each group for pathological examination. All pigs were clinically inspected and then exsanguinated after electric stunning.

The dead weight of the pigs and (after a few seconds of drying on a blotting-pad) the wet weight of the uterus and ovaries were measured with electric scales with a precision of 10 and $0.01 \mathrm{~g}$, respectively. Parallel with the detailed macroscopic pathological examination, samples were taken from the spleen, kidneys, adrenals, thyroid gland, thymus, inguinal lymph nodes and from the ovaries, uterine horns, vagina and mammary glands. Tissue samples were fixed with buffered formaldehyde of neutral $\mathrm{pH}$ (7.2) and then embedded in paraffin with the help of Shandon-Elliot embedding and Lignefer block-automats. These blocks were sliced by a Reichert sleight-microtome into 5-micrometer-thick tissue sections and stained with haematoxillin-eosine in ShandonElliot staining-automat.

The effects of ZEA treatment on the internal genital organs was studied by the stage of follicular development in the ovaries, by the state of the glandular layer of the endometrium and by the degree of proliferation of the stratified epithelium in the vagina. The stage of hyperplasia of the Malpighi bodies in the spleen and blast transformation of lymphocytes in germinal centres of lymph nodes was indicative of the effects of ZEA. For statistical evaluation, the main macroscopic and histological findings were scored as follows:

Ovaries: 1 = only primary and secondary follicles are present, $2=$ one or two tertiary follicles are present, $3=$ more than two tertiary follicles are present. Uterus: $1=$ infantile endometrium, $2=$ slight development of endometrial glandular layer, 3 = marked development of endometrial glandular layer (proliferation). Vagina: $1=$ thin epithelial layer $(2-5$ cellular layer), $2=$ slight proliferation of the epithelial layer $(5-10$ cellular layer), 3 = marked proliferation of the epithelial layer (10-20 cellular layer). Spleen and lymph nodes: 1 = slight blast transformation of lymphocytes, $2=$ moderate blast transformation of lymphocytes, $3=$ marked blast transformation of lymphocytes.

At autopsy, liver samples were taken from each pig and used for determination of ZEA and its metabolites ( $\alpha$ - and $\beta$-Zearalenol) by the method described by Bata et al. (1989).

For analysis of differences in the body weight, the weight of the ovaries and uterus, and score numbers of the ovaries, uterus, vagina, spleen and lymph nodes in the groups, one-way ANOVA was applied. Post hoc analysis was done for all possible comparisons. Because of multiple comparisons the raw $P$-values were adjusted by Bonferroni method. As for studying the effects of ZEA and parallel use of Detoxa Plus on the ZEA/metabolite concentration of liver samples, Wilcoxon Mann-Whitney rank sum test was applied to compare the group-pairs (group 3 and 4; group 5 and 6). Calculation of the $P$-value was based on Monte-Carlo resampling; results with $P<0.05$ were considered significant.

\section{Results}

At the time of exsanguination, the weight, size and conformation of the pigs were characteristic for the breed, age and sex (Table 1).

Statistical analysis has revealed no significant differences $(P<0.05)$ among weight of groups attributable to the treatments. Daily weight gain for different periods of the 
Table 1. Experimental design and the live weight of pigs.

\begin{tabular}{|c|c|c|c|c|c|}
\hline Group & Treatment & Weaning & $\begin{array}{l}60 \text { days } \\
\text { of age }\end{array}$ & $\begin{array}{l}70 \text { days } \\
\text { of age }\end{array}$ & $\begin{array}{l}90 \text { days } \\
\text { of age }\end{array}$ \\
\hline 1 & $\begin{array}{l}\text { Control: no zearalenone and no } \\
\text { Detoxa Plus }\end{array}$ & $8.4 \pm 0.3$ & $12.2 \pm 0.2$ & $17.6 \pm 0.4$ & $25.9 \pm 0.5$ \\
\hline 2 & $\begin{array}{l}\text { Control: no zearalenone }+1 \mathrm{~kg} \\
\text { Detoxa Plus } / \mathrm{mt} \text { feed }\end{array}$ & $8.4 \pm 0.2$ & $12.2 \pm 0.2$ & $17.9 \pm 0.3$ & $28.0 \pm 0.4$ \\
\hline 3 & $\begin{array}{l}\text { Experimental: } 8 \mathrm{mg} / \text { pig } \\
\text { zearalenone on every other } \\
\text { day and no Detoxa Plus }\end{array}$ & $8.4 \pm 0.2$ & $12.4 \pm 0.3$ & $18.5 \pm 0.4$ & $26.8 \pm 0.5$ \\
\hline 4 & $\begin{array}{l}\text { Experimental: } 8 \mathrm{mg} / \mathrm{pig} \\
\text { zearalenone on every other } \\
\text { day }+1 \mathrm{~kg} \text { Detoxa Plus } / \mathrm{mt} \text { feed }\end{array}$ & $8.3 \pm 0.2$ & $11.9 \pm 0.4$ & $18.2 \pm 0.4$ & $27.8 \pm 0.4$ \\
\hline 5 & $\begin{array}{l}\text { Experimental: } 16 \mathrm{mg} / \mathrm{pig} \\
\text { zearalenone on every other day } \\
\text { and no Detoxa Plus }\end{array}$ & $8.3 \pm 0.2$ & $12.4 \pm 0.2$ & $18.6 \pm 0.4$ & $28.2 \pm 0.9$ \\
\hline 6 & $\begin{array}{l}\text { Experimental: } 16 \mathrm{mg} / \mathrm{pig} \\
\text { zearalenone on every other } \\
\text { day }+1 \mathrm{~kg} \text { Detoxa Plus } / \mathrm{mt} \text { feed }\end{array}$ & $8.3 \pm 0.2$ & $12.0 \pm 0.4$ & $17.9 \pm 0.2$ & $28.0 \pm 0.2$ \\
\hline
\end{tabular}

The weight of pigs is in $\mathrm{kg} \pm$ standard deviation, $\mathrm{mt}$ - metric tonne

Table 2. Weight of ovaries and uterus of pigs at different phases of the experiment after zearalenone treatment.

\begin{tabular}{|c|c|c|c|c|c|c|c|}
\hline \multirow{2}{*}{ Group } & \multirow{2}{*}{ Treatment } & \multicolumn{3}{|c|}{ Weight of ovaries } & \multicolumn{3}{|c|}{ Weight of the uterus } \\
\hline & & Day 60 & Day 70 & Day 90 & Day 60 & Day 70 & Day 90 \\
\hline 1 & $\begin{array}{l}\text { Control: no zearalenone } \\
\text { and no Detoxa }\end{array}$ & $0.9 \pm 0.3$ & $1.2 \pm 0.1^{\mathrm{a}}$ & $1.6 \pm 0.1^{\mathrm{a}}$ & $10.4 \pm 0.7$ & $12.6 \pm 0.8^{\mathrm{a}}$ & $17.9 \pm 1.3^{\mathrm{a}}$ \\
\hline 2 & $\begin{array}{l}\text { Positive Control: } \\
\text { no zearalenone }+1 \mathrm{~kg} \\
\text { Detoxa } / \mathrm{mt} \text { feed }\end{array}$ & $1.1 \pm 0.3$ & $1.3 \pm 0.2$ & $1.6 \pm 0.2^{a}$ & $10.2 \pm 1.8$ & $15.9 \pm 5.5^{\mathrm{a}}$ & $18.39 \pm 2.4^{a}$ \\
\hline 3 & $\begin{array}{l}\text { Experimental: } 8 \mathrm{mg} / \mathrm{pig} \\
\text { zearalenone on every } \\
\text { other day and no Detoxa }\end{array}$ & $1.0 \pm 0.2$ & $1.4 \pm 0.2$ & $2.1 \pm 0.3^{b}$ & $9.4 \pm 0.9$ & $15.4 \pm 1.1^{\mathrm{b}}$ & $27.2 \pm 2.8^{b}$ \\
\hline 4 & $\begin{array}{l}\text { Experimental: } 8 \mathrm{mg} / \mathrm{pig} \\
\text { zearalenone on every other } \\
\text { day }+1 \mathrm{~kg} \text { Detoxa } / \mathrm{mt} \text { feed }\end{array}$ & $0.9 \pm 0.2$ & $1.2 \pm 0.3$ & $1.4 \pm 0.3^{\mathrm{c}}$ & $9.2 \pm 1.8$ & $12.5 \pm 2.3^{\mathrm{c}}$ & $13.6 \pm 3.0^{c}$ \\
\hline 5 & $\begin{array}{l}\text { Experimental: } 16 \mathrm{mg} / \mathrm{pig} \\
\text { zearalenone on every other } \\
\text { day and no Detoxa }\end{array}$ & $1.2 \pm 0.3$ & $1.9 \pm 0.1^{\mathrm{b} ; \mathrm{d}}$ & $2.6 \pm 0.5^{\mathrm{d}}$ & $11.5 \pm 0.8$ & $16.3 \pm 4.3^{\mathrm{d}}$ & $19.6 \pm 1.3^{f}$ \\
\hline 6 & $\begin{array}{l}\text { Experimental: } 16 \mathrm{mg} / \mathrm{pig} \\
\text { zearalenone on every other } \\
\text { day }+1 \mathrm{~kg} \text { Detoxa } / \mathrm{mt} \text { feed }\end{array}$ & $0.9 \pm 0.3$ & $1.3 \pm 0.3^{\mathrm{e}}$ & $1.7 \pm 0.3^{\mathrm{e}}$ & $11.5 \pm 1.1$ & $11.8 \pm 2.2^{\mathrm{e}}$ & $13.6 \pm 3.0^{\mathrm{e}}$ \\
\hline
\end{tabular}

The weight of ovaries and uterus are in $\mathrm{kg} \pm$ standard deviation, $\mathrm{mt}$ - metric tonne.

Numbers superscripted with ${ }^{\mathrm{a}-\mathrm{b}}$; ${ }^{\mathrm{a}-\mathrm{d}}$; ${ }^{\mathrm{b}-\mathrm{c}}$; ${ }^{\mathrm{d}-\mathrm{e}}{ }^{\mathrm{c}-\mathrm{a}}{ }^{\mathrm{a}}$ and ${ }^{\mathrm{f}-\mathrm{e}}$ within the same column differ significantly $(P \leq 0.05)$ 


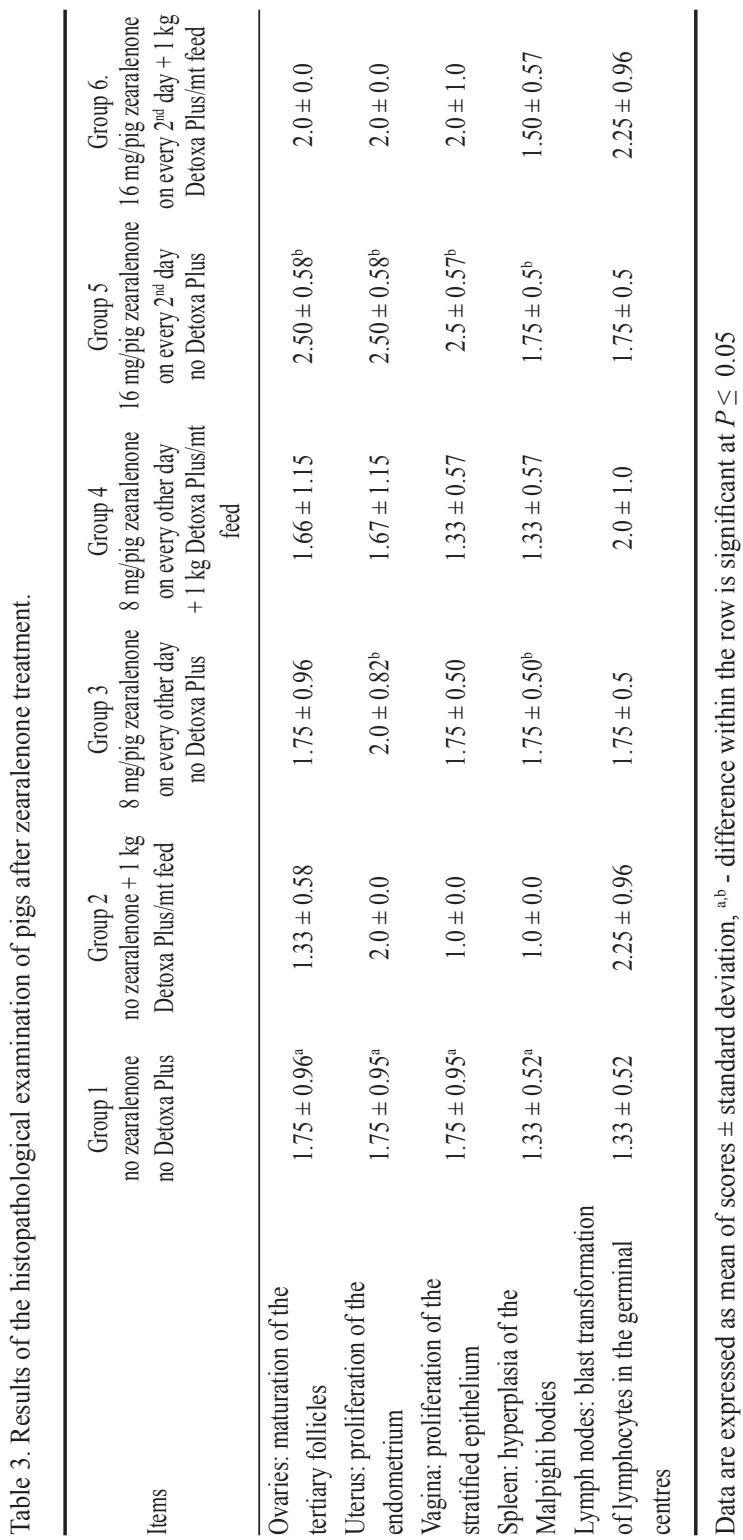

experiment was also calculated (data are not shown) and no significant differences were found among the groups. As can be seen from Table 2, ZEA treatment had no effect on the ovaries after 10 days of treatment (60 days of age). However, 10 days later, the ovaries of pigs treated with a higher dose of ZEA had a significantly higher weight $(P<0.05)$. The feed additive kept the ovarian weights at the level of the control groups. At 90 days of age, the average weight of the ovaries of pigs in Groups 3 and 5 increased significantly $(P<0.05)$ over that of the controls. These weight increases were efficiently prevented by incorporating the feed additive in the diet of Groups 4 and 6 . The same applies for the weight of the uterus. While no effects of ZEA treatment was seen in either of the groups on Day 60, ZEA treatment yielded a considerable weight increment of the uterus at Days 70 and 90.

At autopsy, no pathological signs were seen on the skin and around external genitals of the control and experimental pigs. Pigs of Groups 3 and 5 had a slightly enlarged, purplereddish vulva. The signs were more expressed at the higher dose. Joints, muscle and subcutaneous tissue have proven intact in all pigs. The size of regional lymph nodes seemed normal. Serosa membranes of body cavities were intact. The shape, size, colour and palpation of the internal organs as well as the dissected surfaces looked normal, with the exception of the genital organs. The histopathological findings are summarised in Table 3. Data in the table represent the group means irrespective of the time of exsanguination.

Toxin treatment at the higher dose enhanced the development of ovarian follicles $(P<0.05)$. Supplementation of the feed with Detoxa Plus tended to $(P<0.12)$ alleviate this effect. The higher dose of ZEA had proliferative effects on the uterine glandular layers $(2.50 \pm 0.58$ vs. $1.75 \pm 0.95 ; P \leq 0.05)$ and the feed additive tended to alleviate this effect. 
Table 4. Zearalenone and zearalenone metabolite ( $\alpha$ - and $\beta$ zearalenone) content in the liver of pigs $(\mathrm{mg} / \mathrm{kg} \pm \mathrm{SD})$ on Day 20 after zearalenone treatment.

\begin{tabular}{|c|c|c|c|c|}
\hline Group & Treatment & Zearalenone & $\alpha$-zearalenone & $\beta$-zearalenone \\
\hline 3 & $\begin{array}{l}8 \mathrm{mg} / \text { pig zearalenone on every other day } \\
\text { and no Detoxa Plus }\end{array}$ & $43.3 \pm 0.3^{\mathrm{a}}$ & $111.3 \pm 17.5^{\mathrm{a}}$ & $36.3 \pm 13.1^{\mathrm{a}}$ \\
\hline 4 & $\begin{array}{l}8 \mathrm{mg} / \mathrm{pig} \text { zearalenone on every other } \\
\text { day }+1 \mathrm{~kg} \text { Detoxa Plus } / \mathrm{mt} \text { feed }\end{array}$ & $18.3 \pm 2.9^{b}$ & $30.0 \pm 8.7^{b}$ & $13.3 \pm 2.9^{b}$ \\
\hline 5 & $\begin{array}{l}16 \mathrm{mg} / \text { pig zearalenone on every other } \\
\text { day and no Detoxa Plus }\end{array}$ & $61.7 \pm 11.1^{\mathrm{c}}$ & $155.0 \pm 14.9^{c}$ & $56.7 \pm 9.1^{\mathrm{c}}$ \\
\hline 6 & $\begin{array}{l}16 \mathrm{mg} / \text { pig zearalenone on every other } \\
\text { day }+1 \mathrm{~kg} \text { Detoxa Plus } / \mathrm{mt} \text { feed }\end{array}$ & $36.7 \pm 6.3^{\mathrm{d}}$ & $56.7 \pm 6.3^{\mathrm{d}}$ & $16.7 \pm 4.1^{\mathrm{d}}$ \\
\hline
\end{tabular}

a,b c,d - difference within the column is significant $(P \leq 0.05)$

At the smaller dose of ZEA, the feed supplement reduced the negative effects of ZEA $(2 \pm 0.82$ vs. $1 \pm 00 ; P \leq 0.05)$.

The lower dose of ZEA had no effect on proliferation of the stratified epithelium of the vagina. The higher dose of ZEA thickened this layer significantly $(P<0.05)$. Supplementation of the feed with the feed supplement reduced the proliferation of the stratified epithelium layer of vagina; however, the differences of the means were nonsignificant.

Malpighi bodies in the spleen reacted to treatment with ZEA with hyperplasia. The effect was seen at the smaller dose, which was not increased by doubling the dose of the toxin. Neither treatment with ZEA, nor supplementation with the feed additive had an effect on blast transformation of lymphocytes in the germinal centres of lymph nodes.

Table 4 summarises the concentration $(\mathrm{mg} / \mathrm{kg} \pm$ SD) of ZEA and its metabolites $(\alpha$ - and $\beta$-Zearalenol) of the liver samples. Obviously no ZEA and metabolite was found in the liver of the two control groups. Differences were seen on Day 10 of the treatment and on Day 20 after ending the toxin treatment between means of ZEA/metabolite concentrations in liver of Groups 3 and 4 and between Groups 5 and 6. Statistical analysis revealed no consistent treatment effects; therefore, the values are not shown in Table 4 . The liver of pigs sacrificed on Day 20 of toxin treatment had higher ZEA/metabolite concentrations in Groups 3 and 5 compared to Groups 4 and 6, respectively, and the differences between Groups 3 and 4, and between Groups 5 and 6 were significant at $P<0.05$ (Table 4).

\section{Discussion}

The results of our study revealed no weight change of the experimental and control pigs attributable to the treatment with zearalenone. This finding is consistent with earlier observations by e.g. Friend et al. (1990).

The weight of ovaries and uterus of untreated control and positive control pigs (Group 1 and 2, respectively) were comparable to those described by Stephan et al. (2007). The weight increase found in our study on Days 70 and 90, respectively, was comparable with earlier observations (e.g. Friend et al. 1990). Ványi et al. (1994) treated gilts and sows with zearalenone and found enlarged ovaries with signs of follicle maturation, glandular proliferation in the endometrium and epithelial proliferation in the vagina in addition to oedema and hyperaemia. Their finding supports our results.

In summary, we may state that treating pigs with ZEA provoked characteristic changes in the genital organs. Supplementation of the feed with the additive Detoxa Plus reduced 
the undesirable effects of zearalenone. The positive effects of the feed supplement included prevention of ovarian and uterine enlargement, beneficial effects on the histopathological scores of the ovaries, uterus and vagina. The reduced concentration of ZEA and its metabolites in the liver of pigs fed with rations supplemented with the feed additive provided evidence about the efficiency of Detoxa Plus.

\section{Acknowledgement}

Part of this research was supported by the TÁMOP-4.2.1.B-11/2/KMR-2011-003 project.

\section{References}

Anonymous 2004: Opinion of the scientific panel on contaminants in the food chain on a request from the Commission related to Zearalenone as undesirable substance in animal feed. EFSA Journal 89: 1-35

Bata Á, Lásztity R 1999: Detoxification of mycotoxin-contaminated food and feed by microorganisms. Trends Food Sci Technol 10: 23-228

Bata Á, Palyusik M, Lásztity R 1989: Investigation of the distribution of zearalenone and its metabolites in the pigs fed with feed contaminated by zearalenone. Period Polytech 33: 203-209

Friend DW, Trenholm HL, Thompson BK, Hartin KE, Fiser PS, Asem EK, Tsang BK 1990: The reproductive efficiency of gilts fed very low levels of zearalenone. Canadian J Anim Sci 70: 635-645

Halász A, Lásztity R, Abonyi T, Bata Á 2009: Decontamination of mycotoxin-containing food and feed by biodegradation. Food Rev Int 25: 284-298

Heidler D, Schatzmayr G 2003: A new approach to managing mycotoxins. WP Reed 19: 12-15

Lawley R, Curtis L, Davis D 2008: The food safety hazard guidebook. RSC Publishing, 224 p.

Rafai P 1999: Opportunities of defence against mycotoxins (In Hungarian). Állattenyésztés és Takarmányozás 48: $427-438$

Stephan K, Kauffold J, Wähner M 2007: Zearalenone and its effects on sow and piglets. Res Pig Breeding 1: 1-3 Ványi A, Bata Á, Glávits R, Kovács F 1994: Perinatal oestrogen syndrome in swine. Acta Vet Hung 42: $433-446$

Zinedine A, Soriano JM, Moltó JC, Manes J 2007: Review on the toxicity, occurrence, metabolism, detoxification, regulations and intake of zearalenone: An oestrogenic mycotoxin. Food Chem Tox 45: 1-18 